\title{
THE IMPACT OF BREXIT ON EMPLOYMENT LAW IN SCOTLAND
}

\author{
Rebecca Zahn*
}

\section{A. INTRODUCTION}

In the run-up to the 'Brexit' referendum, workers' rights were invoked repeatedly by both sides of the campaign as either a reason to back or oppose a British exit from the EU. Following the referendum, the debate over workers' rights and their continuing protection once the UK leaves the EU, has been reignited. The Scottish Government has expressed particular concern about Brexit's potential impact on social rights, including the rights of workers $^{1}$, and is considering how Scotland can maintain protection of EU-derived rights in this area once the UK leaves the EU. ${ }^{2}$ What then is Brexit's potential impact on employment law in Scotland?

\section{B. THE DEVOLUTION SETTLEMENT}

Employment and industrial relations, health and safety, and most aspects of equal opportunities are reserved matters under Schedule 5 Part 2, Head H of the Scotland Act 1998. Although the Scotland Act 2016 gave the Scottish Parliament greater powers in the field of equal opportunities ${ }^{3}$ and devolved employment tribunals ${ }^{4}$, the key European rights are implemented almost exclusively through UK legal sources. While there are some minor differences between the employment laws applicable in Scotland and England - including common law rules on the formation of contract ${ }^{5}$, the treatment of third party rights ${ }^{6}$ and rules on prescription/limitation ${ }^{7}$ - these do not touch upon areas impacted by EU-derived employment laws.

\section{THE EU'S INFLUENCE ON UK EMPLOYMENT LAW}

Apart from the provisions in the Treaty on the Functioning of the European Union (TFEU) which enable the EU institutions to act in order to facilitate the free movement of workers ${ }^{8}$, the EU has limited competence to legislate in employment matters. Any attempts which have been made to introduce a comprehensive European labour law - largely under the banner of a so-called European Social Model - have therefore been dependent on the effective

\footnotetext{
Senior Lecturer in Law, University of Strathclyde.

${ }^{1} \mathrm{http} / / \mathrm{www} . \mathrm{gov} \cdot \mathrm{scot} /$ Resource/0051/00510265.pdf

2 http://www.gov.scot/Publications/2017/09/8468.

3 Section 37.

${ }^{4}$ Section 39.

${ }^{5}$ See further W W McBryde, The Law of Contract in Scotland, 3rd edn (2007).

${ }^{6}$ See H MacQueen, "Third Party Rights in Contract”, in K Reid and R Zimmerman (eds), A History of Private Law in Scotland (2000). For a thorough review of this area of the law see the Scottish Law Commission's report on Third Party Rights available here:

http://www.scotlawcom.gov.uk/files/2014/6850/9379/Review of Contract Law -

Report on Third Party Rights No 245.pdf.

${ }^{7}$ See further McBryde, Contract.

${ }^{8}$ Article 45 TFEU.
} 
accommodation of political interests. ${ }^{9}$ Nonetheless, legislation adopted under the European Social Model has bestowed a number of individual - including substantial equality and health and safety rights - and collective employment rights on workers in the UK and has led to the establishment of a floor of social rights which limits the UK Government's legislative capabilities. In addition, EU law provides guarantees for the protection and enforcement of employment rights, ${ }^{10}$ and the Court of Justice of the European Union (CJEU) has used the general principles of EU law to progressively widen the scope of protections and rights granted to workers under EU law. ${ }^{11}$ The CJEU's case law can be contrasted with the approach of UK courts which have tended to interpret employment rights narrowly. ${ }^{12}$

Overall, therefore, EU-derived employment laws cover a patchwork of rights in the UK. Although it is difficult to predict what would have happened if the UK had never joined the EU, it is likely that some of these rights would have been enacted anyway, and in some instances, the UK has gone further than required under EU law. ${ }^{13}$ In other cases, EU rules have introduced rights into UK employment law which sit uneasily with the British system of industrial relations ${ }^{14}$ and their effect has therefore been limited. Yet none of this negates the largely positive effect that EU membership has had on UK employment law. Under successive Conservative governments between 1979 and 1997, social legislation originating from the EU was widely seen as the only positive development for trade unions and workers' rights in British labour law. ${ }^{15}$ The overall framework created by EU law, which includes not only positive rights in legislation and case law but also rights to enforcement and effective remedies, constrains government action and creates a minimum floor of rights for workers in one of the least regulated labour markets amongst OECD countries. ${ }^{16}$

\section{BREXIT'S POTENTIAL IMPACT}

The impact of Brexit on employment law is, for obvious reasons, difficult to predict. Much depends on the future relationship between the EU and the UK. Potential options that have been discussed include (continued) membership of the European Economic Area (EEA) and/or the European Free Trade Association (EFTA); a series of bilateral deals with the EU; or a 'hard' Brexit whereby the UK exits both the single market and the customs union. Should the UK negotiate membership of the EEA, then most EU laws on workers' rights would continue to apply and future EU laws in this area would need to be implemented by the UK government, and would therefore apply in Scotland. The case law of both the EFTA Court and the CJEU would be of relevance. Under the 'bilateral' option, it is likely that the

\footnotetext{
${ }^{9}$ U Weinstock, "Europäische Sozialunion - historische Erfahrungen und Perspektiven“, in W Däubler (ed), Sozialstaat EG? Die andere Dimension des Binnenmarktes (1989).

${ }^{10}$ A detailed overview of EU-derived employment rights can be found elsewhere. See M Ford QC, Workers' Rights from Europe: The Impact of Brexit (2016) available at https://www.tuc.org.uk/internationalissues/europe/eu-referendum/workers $\% \mathrm{E} 2 \% 80 \% 99$-rights-europe-impact-brexit.

${ }^{11}$ See, for example, Case C-555/07 Seda Kücükdeveci v Swedex GmbH \& Co. KG [2010] ECR I-00365.

${ }^{12}$ For a further discussion see M Ford, "The Impact of Brexit on UK Labour Law" (2016) 32(4) International Journal of Comparative Labour Law and Industrial Relations 473.

13 This is often referred to as 'gold-plating'. Examples include minimum holiday or maternity leave entitlements.

${ }^{14}$ For example the rules on information and consultation.

${ }^{15}$ R Hyman, "Trade Unions and "Europe": Are the Members out of Step?" LEQS Paper No 14/2009 at 26.

${ }^{16}$ According to the OECD's employment protection index, the UK comes in at 31 out of 34 rich countries available here: http://www.oecd.org/els/emp/oecdindicatorsofemploymentprotection.htm.
} 
UK will continue to have to abide by EU employment laws so as to prevent distortions of competition. However, in both scenarios, the UK would be subject to EU law from a position of non-membership which does not bring with it the ability to shape those same laws in a cooperative way with the UK's nearest neighbours, nor to access the remedies and state accountability checks that the EU offers to individuals and businesses such as access to the Court of Justice. Finally, the EU also has an impact on the coordination of economic and employment policies across the EU through the European Semester Process; an annual process promoting policy coordination among EU Member States and EU Institutions. ${ }^{17}$ Access to and involvement in this structured form of policy coordination and knowledge exchange - which the Scottish Government has actively fed into in the past - will fall away after Brexit.

In the event of a 'hard' Brexit and in the absence of an obligation to abide by any EU rules, the UK could seek competitive advantages by implementing labour standards that are less onerous for employers than those required of their counterparts in the European Union. ${ }^{18}$ Brexit may well therefore fortify the prevailing deregulatory approach to employment protection and further entrench the neo-liberal reconfiguration of the UK's labour market. ${ }^{19}$ If existing EU trade agreements are to serve as a template for a future EU-UK post-Brexit relationship then it is probable that a labour clause may be inserted. A future trade deal, if at all sophisticated, will likely also include provisions on public services including privatisation, may challenge any kind of variation of social policy and may include elements related to labour movement (for example in relation to intra-company transfers or posted work). However, these provisions are unlikely to include any great social protections or positive employment rights. Some form of indirect EU influence over UK employment laws may well however continue post-Brexit.

\section{E. THE EUROPEAN UNION (WITHDRAWAL) BILL}

Brexit will have consequences for the majority of EU employment laws which have been implemented into UK law by virtue of secondary legislation made under the framework of the European Communities Act 1972. An example can be found in the Agency Worker Regulations $^{20}$. The Government, on 13 July 2017, therefore published the European Union (Withdrawal) Bill (EUW Bill) $^{21}$ which repeals the European Communities Act 1972 (ECA)

\footnotetext{
${ }^{17}$ See further Scotland's Plan for EU Engagement available at http://www.gov.scot/Resource/0047/00473826.pdf and Europe 2020:Scottish National Reform Programme 2016 available at http://www.gov.scot/Resource/0049/00497957.pdf.

18 This was threatened by the Chancellor, Philip Hammond. See https:/www.welt.de/englishnews/article161182946/Philip-Hammond-issues-threat-to-EU-partners.html. Indeed, some of the Beecroft proposals fall foul of EU law and could be revived post-Brexit. See A Beecroft, Report on Employment Law, (2011) and B Hepple, "Back to the Future: Employment Law under the Coalition Government" (2013) 42(3) Industrial Law Journal 203.

${ }^{19}$ See L Dickens, "The Coalition government's reforms to employment tribunals and statutory employment rights - echoes of the past" (2014) 45 Industrial Relations Journal 234 and P Smith, "Labour under the law: a new law of combination, and master and servant, in $21^{\text {st }}$-century Britain?" (2015) 46(5) Industrial Relations Journal 345.

${ }^{20}$ SI 2010/93.

${ }^{21}$ An excellent overview of the different pieces of scholarly writing exploring legal aspects of the Bill, including the implications for devolution can be found here: https://ukconstitutionallaw.org/tag/european-unionwithdrawal-bill/ and https://publiclawforeveryone.com/2017/07/18/resources-the-eu-withdrawal-bill/.
} 
with effect on 'exit day' (clause 1), ends the (future) supremacy of EU law in UK law, and converts EU law as it stands at the moment of exit into domestic law. The main provisions of the EUW Bill provide for the creation of a new distinct body of law ('retained EU law'); the creation of broadly-framed delegated powers for Government to amend this body of law; new instructions to the courts on how to interpret retained EU law; and amendments to the legislation that underpin devolution. The Bill raises two particular concerns for EU-derived employment laws.

First, the EUW Bill raises concerns over the future interpretation of EU-derived employment laws by UK courts and does not clarify how UK courts are to approach cases which deal with EU-derived employment laws that are pending on 'Brexit day'. Clause 5(2) retains the principle of supremacy of EU law but only as it applies to the interpretation of retained EU law. A post-Brexit Act of Parliament which conflicts with or overturns EUderived employment laws would therefore take precedence. It is also not clear which would prevail in the event of a clash between the common law and retained EU law post-Brexit. Clause 4 of the Bill includes any remaining 'rights, powers, liabilities, obligations, restrictions, remedies and procedures' as part of 'retained EU law' which are available in domestic law through section 2(1) of the ECA prior to 'exit day'. This will include rights under EU treaties and directly effective provisions of directives. This presumably means that directives that have not been properly implemented pre-Brexit could be relied upon directly post-Brexit, presuming that direct effect had been established by exit day. In addition, clause 6(3) provides that all relevant case law of the CJEU decided before Brexit day, including general principles of EU law, should be used by British courts to determine the 'validity, meaning and effect' of retained EU law. ${ }^{22}$ However, clause 6(1) clarifies that British courts will not be bound by post-Brexit CJEU judgments and Schedule 1 of the Bill states that there is no right of action based on a breach of the general principles. It is not clear therefore whether direct effect will continue post-Brexit in relation to retained EU law and what status is to be given to general principles. Any unilateral interpretation by UK courts of EU-derived employment laws post-Brexit in line with future jurisprudence of the CJEU (which is permissible under clause 6(2)) could also be overturned by an Act of Parliament.

Second, the so-called Henry VIII clauses contained in clauses 7-9 of the EUW Bill ${ }^{23}$ raise particular concerns. Henry VIII clauses have been extensively used in the past in relation to social legislation and it would not be surprising to see government take avail of these powers in relation to some EU-derived employment laws which have proved to be controversial. ${ }^{24}$. These include laws on information and consultation on collective redundancies; rules on working time; some of the EU-derived health and safety regulations; parts of the regulations which protect workers in the event of a transfer of undertaking; legislation protecting agency workers; and, some elements of discrimination law to which businesses object most strongly such as liability for equal pay. Particularly the working time

\footnotetext{
${ }^{22}$ An example of where the CJEU relied on a general principle in order to grant rights to workers can be found in Case C-144/04 Mangold v Helm [2005] ECR I-09981.

${ }^{23}$ See also the Delegated Powers Memorandum accompanying the Bill available here: http://services.parliament.uk/bills/2017-19/europeanunionwithdrawal/documents.html.

${ }^{24}$ An example can be found in section 32 of the Employment Act 2002 which limited access to justice for workers (now repealed).
} 
rules and the agency workers' regulations have been criticised by successive UK Governments and some form of amendment or repeal without adequate parliamentary scrutiny or oversight is possible especially if the extremely broad wording of clauses 7-9 is maintained.

\section{F. CONCLUSION}

In the context of the current devolution settlement there is little scope for Scotland to unilaterally preserve EU-derived employment laws in the face of Westminster opposition. Although there is some overlap with areas that are devolved, such as health, private international law or public procurement, any attempts to affect employment law through such related areas would require a high degree of legislative creativity. However, with the pending devolution of the management and operation of employment tribunals to the Scottish Parliament coupled with the concerns outlined above, it seems at least likely that the Scottish Government will seek greater powers over substantive employment and equality rights and duties in a post-Brexit UK, for example in the field of health and safety where the reserved nature of the matter has long been contentious and where practical enforcement already takes place through the Scottish criminal justice system. ${ }^{25}$ Calls for the devolution settlement to be re-visited in the field of employment law may well therefore resurface.

\footnotetext{
${ }^{25}$ P Cairney, "Venue Shift following Devolution: When Reserved Meets Devolved in Scotland" (2006) 16(4) Regional and Federal Studies 429 at 440 and the Law Society's evidence to the Smith Commission, set up in the wake of the 'no' vote in the independence referendum held in 2014 where it argued for the devolution of health and safety law in order to increase legal certainty available here: https://www.lawscot.org.uk/media/387968/smith-commission-october-2014-final.pdf p. 33.
} 